A N N A LES

UNIVERSITATIS MARIAE CURIE-SKŁODOWSKA

LUBLIN - POLONIA

VOL. LXXIV

SECTIO B

2019

ZYGMUNT KRUCZEK

ORCID ID: 0000-0003-3015-2139

Department of Tourism and Recreation

University School of Physical Education

Kraków, Poland

zygmunt.kruczek@awf.krakow.pl

\title{
Ways to Counteract the Negative Effects of Overtourism at Tourist Attractions and Destinations
}

Sposoby przeciwdziałania negatywnym skutkom overtourismu

w atrakcjach i destynacjach turystycznych

\begin{abstract}
Abstrakt: Nadmierna koncentracja ruchu turystycznego (overtourism) prowadzi do zatłoczenia atrakcyjnych miejsc oraz przereklamowania i agresywnej komercjalizacji, co obniża poziom estetycznych doznań turystów i skutkuje degradacją naturalnych i kulturowych zasobów. Efektem nadmiernej frekwencji turystów jest wzrost cen usług, mieszkań i nieruchomości. W miastach historycznych dochodzi przez to do gentryfikacji zabytkowych dzielnic. Celem pracy było ukazanie genezy zjawiska zwanego overtourismem, jego rozwoju oraz działań mających na celu ograniczenie jego negatywnych skutków. Artykuł został oparty na przeglądzie literatury oraz na obserwacji zjawisk towarzyszących nadmiernej frekwencji turystów w 2018 r., opisywanych w mediach społecznościowych i identyfikowanych na terenie zabytkowej dzielnicy Krakowa. Omówiono negatywne skutki overtourismu obserwowane w atrakcjach i destynacjach turystycznych, ilustrując ten problem przykładami ze świata i z Polski. Proces gentryfikacji pokazano, posługując się przykładem Krakowa. Ponadto zestawiono opisane w literaturze i doniesieniach medialnych działania na rzecz łagodzenia negatywnych skutków overtourismu. Dotyczą one zarówno działań po stronie podaży ofert usług turystycznych jak i popytu na te usługi. Wskazano na potrzebę budowania kompromisu pomiędzy trzema stronami interesariuszy: mieszkańcami, turystami i branżą turystyczną.
\end{abstract}

Słowa kluczowe: overtourism; zagrożenia; gentryfikacja; Kraków; przeciwdziałania

Abstract: The excessive concentration of tourist traffic, known as overtourism, leads to over-
crowding in attractive locations, over-advertising and aggressive commercialisation, which lower
the aesthetic quality of tourists' experiences and result in the degradation of natural and cultural
resources. The effect of excessive number of tourists is an increase in the price of services, rental
fees and real estate. In historical cities, it causes the gentrification of historical districts. The aim
of this work is to show the genesis of the phenomenon called "overtourism", its development and 
activities aimed at limiting its negative effects. The article is based on a review of literature and observation of phenomena accompanying excessive tourist attendance in 2018 described in social media and identified in the historic district of Kraków. The article discusses the negative effects of overtourism observed at attractions and in tourist destinations, illustrated by examples from Poland and around the world. The process of gentrification is exemplified using the city of Kraków. The second part of the article presents actions described in the literature and media reports that are taken to soften the negative effects of overtourism. This includes both action with regard to the supply of tourist services, as well as the demand for such services. It is indicated that a compromise needs to be reached among the three interested parties: residents, tourists and the tourist industry.

Keywords: overtourism; threats; gentrification; Kraków; countermeasures

\section{INTRODUCTION}

In tourist literature in the last two years, overtourism has been the most commonly discussed topic in both the media and by the scientific community. The excessive presence of tourists leads to congestion in attractive locations, over-advertising and aggressive commercialisation, as well as a subsequent decrease in the level of aesthetic experiences for tourists, and results in degradation of both natural and cultural resources. The effect of excessive visits by tourists is an increase in the price of services, rental fees and real estate, and depopulation in districts exploited by tourism. In cities with a long history, it causes the gentrification of historical areas.

This article discusses the negative effects of overtourism observed at tourist attractions and destinations, illustrating the problem with examples from Poland and around the world. The process of gentrification caused by tourism is exemplified using Kraków, a historical city entered onto the UNESCO cultural and natural heritage list.

The second part of the article presents activities described in the literature and media reports aimed at mitigating the negative effects of overtourism. These include both actions related to the supply of tourist services, as well as the demand for such services. Attention is drawn to the need for a compromise to be reached among the three parties involved: residents, tourists and the tourist industry.

The article is based on a review of the literature and on observation of phenomena accompanying visits of excessive numbers of tourists.

\section{WHAT IS OVERTOURISM?}

The term "overtourism" first appeared in the last few years in media reports on the negative effect of mass tourism on host communities and/or the natural environment. It must be added that the phenomenon is nothing new as the issue 
has been the subject of discussion in academic circles for many years. As early as the 1970s, special indicators were developed to define the optimal size of tourist traffic for various regions. The literature mentions three basic measurements: absorption indicator, capacity indicator and flow indicator (Kostrowicki 1970; Canestrelli et al. 1991). Meanwhile, Butler (1980) published a theory on the evolution cycle of tourist areas, and Doxey (1975) constructed an irritation index illustrating the change in residents' attitudes to tourists.

A tourist area has its limitations resulting from the usable area available and its reaction to tourist traffic (Szromek 2012, p. 35). A key problem is defining the permissible size of traffic, above which it may be considered excessive. For cities that are large centres of tourism and are faced with an invasion of tourists, proposed indicators define the optimal level of socio-psychological capacity (Russo 2002; Mika 2007).

Later research confirmed that the behaviour of visitors, the length of their stay, the volume of tourists and the type of tourism are in fact equally as important as the number of tourists (Lindberg et al. 1997). While the influence of tourism on the physical environment is relatively easy to define, it is decidedly more difficult to assess the social effects of an influx of tourists. A concept based on the host community's tolerance towards tourists is not only subjective, but also difficult to measure. The level of tolerance among residents towards an influx of tourists varies, depending on local and private interests (McCool et al. 2000; Saveriades 2000).

There are also alternative research concepts such as the limits of acceptable change (LAC), which allows for assessment of the degree to which the effect of tourism can be accepted by local parties interested in its development (Lucas et al. 1985; Frauman et al. 2011). In periods of increased financial need, residents may have a more tolerant attitude and endure the negative effects of tourism due to the potential economic benefits. Discussion on the LAC concept and other similar approaches has meant that instead of using figures to illustrate the mass scale of tourist traffic, emphasis has been placed on qualitative analysis balancing the benefits and drawbacks of the development of tourism (Nijs 2017). Various approaches to tourism management have also appeared that go beyond limits on the number of visitors. The first, supported by the United Nations World Tourism Organization (UNWTO), focuses on increasing tourist capacity in reception areas. Capacity can be increased through, amongst others, the use of intelligent hi-tech solutions (UNWTO 2018) or by increasing acceptance in the local community and stimulating entrepreneurship (Pearce 2018). Other approaches focus on the need to diversify forms of tourism and building proper relations between the interested parties involved in tourism. Attention should be drawn to the fact 
that the benefits and drawbacks are often not evenly distributed among the interested parties (Bianchi 2009).

The first use of the term "overtourism" dates back to the beginning of the $21^{\text {st }}$ century, when it was used to describe the danger of excessive exploitation of natural resources. Later, the term "turismofobia" appeared in the Spanish media to describe the reaction of Barcelona residents to the excessive growth of tourism (Milano 2017). The notion of "tourist saturation" was also used to describe excessive saturation of destinations due to tourism (Milano 2017).

The notion of "overtourism" was popularised thanks to the Internet travel website. An official definition of overpopulation also appeared, which reads "the impact of tourism on a destination, or parts thereof, that excessively influences perceived quality of life of citizens and/or quality of visitors' experiences in a negative way" (UNWTO 2018).

In a very short time, the term "overtourism" has come to be used to describe the negative effect of tourism, and has been applied to the problem of excessive numbers of tourists in many cities. The discussion around overtourism has brought attention to the negative consequences of the unchecked increase in tourism. It also pointed to possible limitations and voluntary compromises aimed at effectively preventing the growth of such problems (Russo et al. 2018).

A variety of regulations and formal restrictions on the reception of tourists can be put in place by local authorities or even by the governments of host countries (Jamal et al. 2014). Reports on attempts to limit tourist traffic by limiting the number of tourists are present in the media. For example, in Italy, the mayors of Rome, Venice, Milan and Florence are demanding that action be taken by the Ministry of Culture to limit the influx of tourists by installing electronic gates that lock when a defined limit is reached. The authorities in the Philippines have decided to close the paradise island of Boracay for six months to clean the beaches and allow the natural environment to regenerate. Similar action was taken by Thailand with regard to the famous Maya Bay beach on Phi Phi Leh island.

\section{EXAMPLES FROM POLAND AND AROUND THE WORLD}

Overtourism and the problems related to it can be observed in many European cities, such as Venice, Florence, Barcelona, Rome and Prague, and in Poland - in Zakopane (the Tatra Mountains), Kraków, and Kazimierz Dolny on the Vistula. The most crowded places in Poland are considered to be Kraków, Krupówki Street in Zakopane, Kazimierz Dolny, Morskie Oko lake, Śnieżka mountain and the pier in Sopot (Najbardziej zatłoczone miejsca $w$ Polsce). 
In terms of individual cultural tourist attractions, we can already see excessive numbers of visitors (at certain times of year and at weekends) in famous castles such as Wawel in Kraków, Malbork, Książ, Łańcut, and palaces with gardens in Wilanów and Łazienki in Warsaw. Similar problems are experienced by the Tourist Trail in the Wieliczka Salt Mine, the Copernicus Science Centre in Warsaw, and the Museum of Memory in Auschwitz-Birkenau (Kruczek 2017, p. 129).

Residents in Barcelona and Venice are protesting against excessive development of tourism infrastructure in the city centre (Kowalczyk-Anioł et al. 2017; Kruczek 2017). Residents in Berlin are tired of tourists, calling them "terrotourists", and have had enough of the rattling of suitcase wheels. Berlin city centre and the famous Museum Island are undergoing their own form of gentrification ${ }^{1}$, with former residents being forced out by tourists and real estate developers. Mass tourism has brought these cities billions in profits, but has left a negative mark on their development. The effect of excessive numbers of tourists is a rise in the price of services, rental fees and real estate. The quality of catering services has worsened and the city infrastructure is overloaded (Kruczek et al. 2014).

In Poland, a good example of the change in the role of tourism in the life of the city is Kraków, a city that is well known on the domestic and international tourist market, and in 1978 was entered on to the UNESCO List of World Cultural and Natural Heritage sites. Kraków offers tourists a range of accommodation options, with over 150 hotels offering 10,000 rooms. Kraków has good communications links by rail and via road access from the A4 motorway, as well as the rapidly growing Balice airport that now serves 6 million passengers. Kraków's reputation is also enhanced by distinctions it has been awarded such as the European Culture Capital, the UNESCO City of Literature, the European Capital of Gastronomy Culture, the Best European City Tripetc.

Tourism plays a very important economic role in Kraków. In 2017, 12.9 million people visited Kraków as tourists, of which over 3 million were from abroad. In the same year, tourists spent PLN 6.48 billion during their stay, and the GDP created by the tourist industry in Kraków was $8.27 \%$ of the entire GDP for the city. In 2016, the tourist industry in Kraków generated almost 30,000 jobs, which is as many as the Nowa Huta steelworks in its heyday. Taking into account multiplier effects, the city's tourist industry generated over 40,000 jobs, or $10 \%$ of employment in the Kraków economy as a whole. In 2016, total taxes and fees generated directly by the tourist industry and flowing into the city budget reached

\footnotetext{
1 "Gentrification" - a notion with its origins in the English word gentry, meaning a change in the character of a part of a city.
} 
PLN 170 million. Taking into account multiplier effects, the total amount of taxes and fees was PLN 244 million, some 5.25\% of the city's budget income.

Kraków is systematically attracting more and more people, and the economic consequences of the development of tourism are seen by both the city authorities and the tourist industry as considerable (Gaweł 2013). This steady increase in tourist traffic does not only bring a steady income for the city budget and for residents working in the tourist sector by creating jobs, but also causes many social problems. The observed change in the use of the historical districts in the city over to services, known as tourist gentrification, engenders social problems and other issues. The centre of Kraków and the First Old Town District are experiencing depopulation, as tenements are transformed into hotels, hostels and apartments for tourists. Shouting on the streets, all-night parties, loud music from bars and pubs, and the incessant rattle of suitcase wheels have made Kraków a much less comfortable place to live (Wójtowicz 2016). As a result of these nuisances, more than 1,000 permanent residents are leaving the city centre each year (Fig. 1). The properties they leave behind in the Old Town and Kazimierz districts become apartments to let. According to data from the AirDNA2 agency,



Fig. 1. Changes in the number of residents of the First Old Town District in the years 2004-2016 Source: bip.krakow.pl (access: 7.12.2017).

2 https://www.airdna.co/market-data/app/pl/default/krakow/overview (access: 3.06.2018). 
Airbnb alone (the leader in short-term let websites) offers over 5,480 private rooms and apartments for tourists in Kraków. The competitive prices of apartments have meant that a night's stay in the very centre of the city is no longer a luxury. In 2017, more than 11,000 apartments were rented via Airbnb, and recent years have seen an increase in rentals of $63 \%$ annually.

Figure 1 shows the change in the number of residents living in the heart of Kraków in the years 2004-2016. In 12 years, the total has dropped by 15,600 residents, that is almost a third of the total population in this district. The largest fall was in 2005-2006, when as many as 3,715 people left the area.

During the same period, the number of tourists and day-trippers to Kraków increased by 6.65 million, an increase of over $53 \%$. This rapid increase in tourist traffic has strengthened the economic importance of tourism for the city, but has also intensified organisational and social problems.

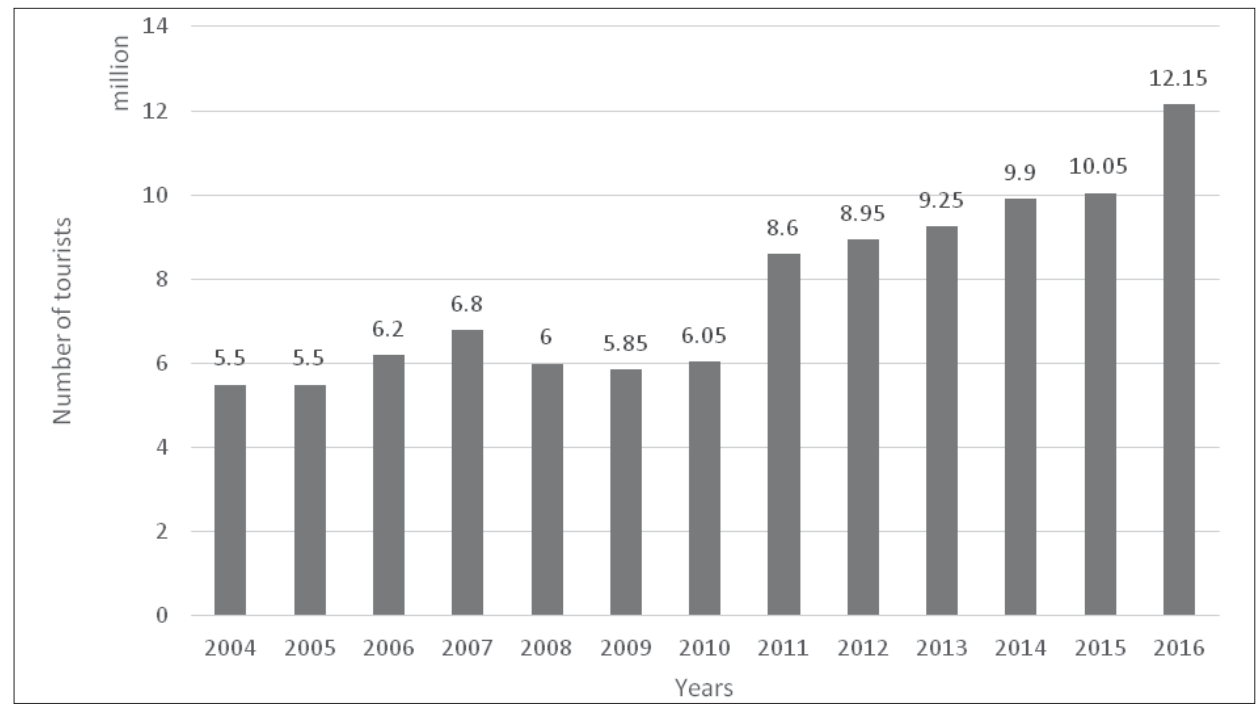

Fig. 2. Tourist and day-tripper visits to Kraków in the years 2004-2016

Source: Author's own study on the basis of Ruch turystyczny w Krakowie... (2017), Tourist traffic in Kraków (2010).

\section{WAYS TO AVOID THE NEGATIVE EFFECTS OF OVERTOURISM}

Milano (2018) identified six negative phenomena that cause dissatisfaction amongst residents. These are:

1. Congestion in city centre public spaces.

2. Privatisation of public spaces. 
3. Increase in cruise ship tourism and the related seasonal changes.

4. Increase in real estate prices (rental and purchase of usable area).

5. Drop in residents' spending power.

6. Imbalance between the number of residents and the number of visitors.

Overtourism, as demonstrated earlier, results in the limits of socio-psychological capacity being exceeded, the effect of which is the dissatisfaction of residents and protests against the development of tourism. The exceeding of capacity limits results in residents' dissatisfaction, which, in turn, affects the "local atmosphere" experienced by tourists. Residents are happy with the development of tourism only in the initial phase of the destination development cycle, in the so-called euphoria phase, during which the influx of tourists is assessed as positive and has a beneficial influence on the local atmosphere. Further development of tourism leads to apathy, irritation and ultimately sours relations between residents and tourists (Doxey 1975; Russo 2002).

Excessive numbers of tourists, in other words overtourism, leads to conflict between three parties:

- residents, who do not want crowds of tourists to disturb their daily lives;

- tourists, who want to put their free time to the best possible use, but also want to relax;

- entrepreneurs, whose aim is to increase profits and continually develop the tourist services they offer.

It is exceedingly difficult to find a solution that is a "perfect balance" and satisfies all interested parties. According to the UNWTO (2018), actions limiting the negative effects of overtourism can be brought down to 11 strategies:

1. Promoting the dispersal of visitors throughout the city and the close vicinity.

2. Promoting the dispersal of visitors over time.

3. Creating new attractions and tourist routes.

4. Reviewing, analyzing and adapting legal regulations to suit organisations and tourism management.

5. Diversifying user segments.

6. Ensuring the local community benefits from tourism.

7. Creating solutions based on previous experience that are beneficial for residents and visitors.

8. Improving urban infrastructure and facilities.

9. Communicating with and involving local interested parties.

10. Communicating with visitors.

11. Monitoring and appropriately responding to adverse phenomena.

The most common action taken is the introduction of bans and the use of penalties, in other words, the implementation of strategy no. 4. The authorities 
in Venice have raised the penalty for littering and inappropriate behaviour in the city centre to EUR 450. Meanwhile, in Berlin, there is a ban on letting apartments via Airbnb due to guests disturbing residents, and in Majorca, a ban was recently introduced on letting apartments in apartment blocks to tourists (Turyści nie wynajma mieszkania na Majorce). In expectation of a mass influx of tourists into Venice at the beginning of May 2018, the city authorities decided to install gates in key locations to regulate tourist traffic. However, in this case, it was representatives of the local tourist industry that protested against the installation (Wenecja ograniczyla ruch turystów. Napięcia przed bramkami). Restrictions are also being introduced in Barcelona, where residents are so furious at the "infuriating tourism" that they have punctured the tyres of excursion coaches (Milano 2017).

As far as Kraków is concerned, a variety of actions are being undertaken that aim to neutralise the negative effects of overtourism. One of these is the dispersal of tourist traffic by creating new attractions in the Podgórze or Nowa Huta districts. The construction of the O. Bernatki footbridge over the Vistula leads tourists out of Kazimierz into Podgórze, where there are new attractions - for example, the Cricoteka and the Podgórze Museum. This has resulted in the opening of new cafés and restaurants, and the holding of various events.

One strategic solution for Kraków is to focus on attracting more affluent tourists, to develop the conference sector, and to support cultural tourism based on visitors interested in participating in many cultural events.

Implementation of the Old Town Culture Park regulations has helped to improve the aesthetics of the historical fabric of the city, but has also created new conflicts with tourism providers. The freedom to conduct business activity in private tenements has allowed owners to let premises for use as hotels, clubs, pubs and restaurants. The Kraków authorities are working on changes to the regulations to limit short-term letting of apartments. For the sustainable development of tourism, however, agreement is needed between the local authority, residents and the tourist industry. This will see the introduction of concessions by both the tourist industry, regarding transport to hotels or coach parking areas, and by residents, who will agree to certain inconveniences related to tourism services.

One of the key problems is defining the tourist capacity in Kraków, in other words, to answer the question: How many tourists is the city able to host? Is $12-13$ million annually the upper limit for the number of tourists in Kraków? A survey conducted showed significant support for further active promotion of the city (Kursa 2017). So, despite the many inconveniences, Kraków residents appreciate the noticeable economic effect of tourism. However, this presents 
the city authorities with the challenge of ensuring that the considerable influx of tourist traffic remains a sustainable phenomenon, while, at the same time, maintaining the high quality of life for residents. In contrast to other cities popular among tourists, the Kraków authorities are not willing to introduce limits on tourists. Nevertheless, action has been initiated under the auspices of the Culture Park statute to relieve the centre of Kraków of the excessive amount of tourist services (limiting the number of electric buggies, vehicles and Segways, as well as sightseeing carriages for tourists, and also the use of megaphones).

\section{Negative phenomena at tourist attractions and ways to mitigate them}

Negative phenomena related to excessive numbers of visitors at tourist attractions have been described by authors such as Garrod (2003) and Nowacki (2014), and include overcrowding, degradation of an attraction's resources, destructive effects on the local community, and detracting from the attraction's authenticity.

A variety of traffic management techniques are used to counteract the negative effect of visitors on tourist attractions (Garrod 2003; Nowacki 2014):

- queue management: using winding queues (which seem shorter), offering information leaflets for visitors to read while waiting, locating exhibits to disperse queues, moving queues inside the attraction so that visitors can enjoy the atmosphere of the attraction while waiting, providing various forms of entertainment for the people in the queue;

- making the attraction more flexible: lengthening opening times and increasing the number of days the attraction is open, providing more entrances and ticket booths at peak times, increasing the number of staff at times of greater traffic, opening additional areas with cafés and other amenities at peak times, recommending special routes for visiting the attraction in order to ensure a better flow of visitors, training staff to do a variety of jobs in order to move them to more crowded places at peak times;

- increasing the capacity of the attraction by purchasing and providing additional areas for visitors, building new souvenir shops and display halls;

- attraction security: ensuring security personnel and staff in exhibition areas (e.g. volunteers), limiting access to sensitive areas using rope barriers, using glass panels to protect exhibits, paving paths, covering window ledges and other sensitive elements with protective coatings, installing information and warning notices;

- creating attraction replicas in order to protect the original site (e.g. the Lascaux caves, the Crystal Cave in the Wieliczka Salt Mine). 
Other methods for managing visitor traffic at attractions involve managing demand. These techniques include:

- pricing methods: periodically raising prices in order to reduce demand and obtain additional funds for repairing damage caused by visitors, and reducing prices in the low season;

- demand control marketing techniques: promoting the attraction out of season; selling combined tickets for other attractions;

- education and interpretation as a means of affecting the attitude and behaviour of visitors (Garrod 2003; Nowacki 2014; Kruczek 2017).

\section{CONCLUSIONS}

Overtourism is not a new phenomenon and was observed as early as the 1970s, but the phenomenon has intensified and taken on a new dimension due to the development of the sharing economy. However, overtourism is not simply the number of tourists present in destinations, but the problem of tourist capacity, in particular psycho-physical capacity and the level of acceptable change (LAC). Overtourism is not only a problem of an excessive influx of tourists and overuse of infrastructure resources, it is also an issue that includes people commuting to work and day-trippers. Speculation on real estate, use of the Internet for purchases and social media have all contributed to the problems identified as overtourism. The use of technology and intelligent solutions is important, but it will not resolve problems regarding the excessive burden of tourist traffic. What is needed is tailored application of carefully selected strategies that are accepted by all interested parties, i.e. residents, visitors and the tourist industry. Research conducted by the UNWTO in 13 European cities showed that $26 \%$ of respondents see opportunities for the further development of tourism, and 30\% expressed their opposition to imposing limits on the number of tourists (Koens et al. 2018).

\section{REFERENCES}

Bianchi R.V. 2009: The 'critical turn' in tourism studies: A radical critique. Tourism. Geographies, 11(484-504), 492. https://doi.org/10.1080/14616680903262653

Butler R.W. 1980: The concept of a tourist area cycle of evolution: Implications for management of resources. Canadian Geographer, 24(1), 5-12. https://doi.org/10.1111/j.1541-0064.1980. tb00970.x

Doxey G.V. 1975: A causation theory of visitor/resident irritants: Methodology and research inferences, [in:] Proceedings of the Travel Research Association 6th Annual Conference. Travel Research Association, San Diego, 195-198. 
Canestrelli E., Costa P. 1991: Tourist carrying capacity: A fuzzy approach. Annals of Tourism Research, 18(2), 295-311. https://doi.org/10.1016/0160-7383(91)90010-9

Frauman E., Banks S. 2011: Gateway community resident perceptions of tourism development: Incorporating importance-performance analysis into a limits of acceptable change framework. Tourism Management, 32(476), 128-140.

Garrod B. 2003: Managing visitor impacts, [in:] A. Fyall, B. Garrod, A. Leask (eds.), Managing Visitor Attractions. New Directions. Oxford: Butterworth-Heinemann, 124-139.

Gaweł Ł. 2013: Rozwój turystyki a polityka zrównoważonego rozwoju miast historycznych (na przykładzie Krakowa). Turystyka Kulturowa, 10, 39-52.

Jamal T., Camargo B.A. 2017: Sustainable tourism, justice and an ethic of care: Toward the just destination. Journal of Sustainable Tourism, 22, 11-30. https://doi.org/10.1080/09669582.2 013.786084

Koens K., Postma A., Papp B. 2018: Is overtourism overused? Understanding the impact of tourism in a city context. Sustainability, 10(4384). https://doi.org/10.3390/su10124384384

Kostrowicki A.S. 1970: Zastosowanie metod geobotanicznych $w$ ocenie przydatności terenu dla rekreacji i wypoczynku. Przegląd Geograficzny, 42(4).

Kowalczyk-Anioł J., Zmyślony P. 2017: Turystyka miejska jako źródło protestów społecznych: przykłady Wenecji i Barcelony. Turystyka Kulturowa, 2, 7-36.

Kruczek Z., Zmyślony P. 2014: Regiony Turystyczne. Kraków: Proksenia.

Kruczek Z. 2017: Frekwencja w polskich atrakcjach turystycznych 2011-2015. Dynamika, trendy, studia przypadku. Kraków: Proksenia.

Lindberg K., McCool S., Stankey G. 1997: Rethinking carrying capacity. Annals of Tourism Research, 24, 461-465, 467. https://doi.org/10.1016/S0160-7383(97)80018-7

Lucas R.C., Stankey G.H. 1985: Role of Research in Applying the Limits of Acceptable Change System, [in:] Proceedings of the Southern Recreation Research Conference. Myrtle Beach, SC, USA, 1-15.

McCool S.F., Lime D.W. 2001: Tourism carrying capacity: tempting fantasy or useful reality? Journal of Sustainable Tourism, 464(9), 372-388. https://doi.org/10.1080/09669580108667409

Mika M. 2007: Przemiany pod wpływem turystyki na obszarach recepcji turystycznej, [in:] W. Kurek (red.), Turystyka. Warszawa: PWN.

Milano C. 2017: Turismofobia: cuando el turismo entra en la agenda de los movimientos sociales. Marea Urbana, 1, 5-8.

Nijs V. 2017: Resident attitudes towards tourism. Testing the resident empowerment through tourism scale 481 (RETS) in Bruges. MBa Thesis. Vienna: MODUL University.

Nowacki M. 2014: Zarządzanie atrakcjami turystycznymi $w$ świetle aktualnych badań. Folia Turistica, 31, 31-51.

Pearce P.L. 2018: Limiting overtourism. The desirable new behaviours of the smart tourist, [in:] Tourism Intelligence Forum (t-Forum) Global Exchange Conference 2018. Palma de Mallorca.

Russo A.P. 2002: The "vicious circle" of tourism development in heritage cities. Annals of Tourism Research, 29(1), 165-182. https://doi.org/10.1016/S0160-7383(01)00029-9

Russo A.P., Scarnato A. 2018: Barcelona in common: A new urban regime for the $21^{\text {st }}$-century tourist city? Journal of Urban Affairs, 40(4). https://doi.org/10.1080/07352166.2017.1373023 
Saveriades A. 2000: Establishing the social tourism carrying capacity for the tourist resorts of the east coast of 471 the Republic of Cyprus. Tourism Management, 21, 147-156. https://doi. org/10.1016/S0261-5177(99)00044-8

Szromek A. 2012: Wskaźniki funkcji turystycznych. Koncepcja wskaźnika funkcji turystycznej i uzdrowiskowej. Gliwice: Wydawnictwo Politechniki Śląskiej.

Wójtowicz B. 2016: Międzynarodowe uwarunkowania negatywnych konsekwencji ruchu turystycznego w Krakowie. Prace Komisji Geografii Przemysłu Polskiego Towarzystwa Geograficznego, 30(4), 174-186.

\section{INTERNET SOURCES}

https://www.airdna.co/market-data/app/pl/default/krakow/overview (access: 3.06.2018).

Kursa M. 2017: Choć turyści zadeptują miasto, krakowianie chcą ich jeszcze więcej. Gazeta Wybor$c z a, 1.12 .2017$, p. 7. Online: http://krakow.wyborcza.pl/krakow/7,44425,22721114,przystanek-krakow-2017-choc-turysci-zadeptuja-miasto-krakowianie.html?disableRedirects=true (access: 20.11.2018).

Milano C. 2018: Overtourism and tourismphobia: Global trends and local contexts. Ostelea School of Tourism \& Hospitality. Online: https://www.academia.edu/35911428/Overtourism_and_ Tourismphobia_Global_trends_and_local_contexts?auto=download (access: 20.11.2018).

Najbardziej zattoczone miejsca w Polsce. Online: https://www.zadluzenia.com/artykul/najbardziej-zatloczone-miejsca-w-polsce (access: 3.06.2018).

Turyści nie wynajma mieszkania na Majorce. Online: http://www.tur-info.pl/a/50413,,majorka-wynajem-mieszkanie-turysci-rada.html (access: 29.05.2018).

UNWTO, 2018: Overtourism? Understanding and managing urban tourism growth beyond perceptions. Madrid. DOI: https://doi.org/10.18111/9789284419999. Online: https://www.e-unwto. org/doi/pdf/10.18111/9789284420070 (access: 20.11.2018).

Wenecja ograniczyła ruch turystów. Napięcia przed bramkami. Online: http://www.polsatnews.pl/ wiadomosc/2018-04-29/wenecja-ograniczyla-ruch-turystow-napiecia-przed-bramkami/ (access: 5.05 .2018$)$. 